\title{
Test the Effectiveness of Aloe Vera Extract on the Growth of Escherichia coli in vitro
}

\author{
Trimurti Parnomo, Dame Joyce Pohan² \\ ${ }^{1,2}$ Medical Faculty, Universitas Kristen Indonesia, Jakarta, Indonesia \\ Corresponding Author: Trimurti Parnomo
}

\begin{abstract}
Aloe vera is a kind of living pharmacy and has an antibacterial power. The antibacterial substances are saponin, tannin and flavonoid. Previous studies indicate that Aloe vera extracts have antibacterial effects against the growth of positive Gram bacteria, either inhibiting harmful Gram bacteria. The experiment was intended to observe the antibacterial effects of Aloe vera against Escherichia coli colonies. The Aloe vera extract can be done through maceration methods in five concentrations (20\%, $40 \%, 60 \%, 80 \%$ and 100\%). The experiments were using Escherichia coli which were performed on MH agar by Kirby Bauer disc diffusion. The result showed a clear zone near the discs containing Aloe vera extracts in $100 \%$ concentration. So, it can be concluded that Aloe vera has an antibacterial effectivity against the growth of Escherichia coli colonies in vitro.
\end{abstract}

Keywords: Extracts, Aloe vera, Escherichia coli

\section{INTRODUCTION}

Bacteria are one of the prokaryotic unicellular microorganisms that generally do not contain chlorophyll and reproduce by dividing. Some bacteria are pathogenic or have the potential to interfere with human health. One of which is the bacterium Escherichia coli, an opportunistic group of gram-negative bacteria in the form of short rods (cocobasil) in single or paired cells. One of the Enterobacteriaceae family members and normal flora in the intestinal organs contribute to the normal function of these organs. However, these bacteria will become pathogenic if they reach tissues outside the intestinal tissues or their unbalanced colonies in the intestinal organs [1].

Enterobacteriaceae is a family of bacteria that is frequently reported in about $50 \%$ of nosocomial infections. Bacteria that often because nosocomial infections include E. coli, Klebsiella, Enterobacter, Proteus, Providencia and Serratia marcescent. In addition, E. coli is a major cause of urinary tract infection (UTI) and diarrhoea. The clinical manifestations of E. coli infection depend on infection and cannot be distinguished from symptoms caused by other bacteria and are often vague and nonspecific [2; 3]. In addition, less invasive sampling methods and inadequate diagnostic facilities also play a role in this.

Infectious diseases caused by bacteria are diseases that are often found in developing countries such as Indonesia. Among infectious diseases caused by various bacteria that are still a concern is $\mathrm{E}$. coli infection. Many things can cause it; besides sanitation problems, another cause is the possibility of bacterial resistance to antibiotics [3; 4]. Resistance to antibiotics is still a big problem in many countries, including Indonesia. Exposure to antimicrobial drugs on microorganisms can change these microorganisms so that they become resistant to antimicrobials. It causes the drugs to become inactive. The 
emergence of new resistance mechanisms and their spread threatens the treatment of infectious diseases so that patients suffer from the disease for a longer time and can cause death. Surgery, diabetes treatment, cancer chemotherapy, organ transplantation is high risk in the absence of effective antimicrobials to prevent and treat infections. Resistance to antimicrobials initially occurs naturally, usually through changes or modifications to the genome of these microorganisms, but antimicrobial abuse and overuse of antimicrobials can increase the process of resistance [5].

E. coli resistance to various antibiotics has been widely reported. Based on Anti Microbial Resistance Study in Indonesia data, there was an increase in antibiotic resistance against Escherichia coli bacterial isolates. Namely $17 \%$ in 2010 and increased to $52 \%$ in 2012.6 Based on an epidemiological study by Fazeli et al. in Iran, it was found that $\mathrm{E}$ coli is the most common type of germ isolated from stool samples from diarrheal patients and shows a high prevalence of resistance to antibiotics such as penicillin, erythromycin, and tetracycline.7 Quoted from research by $\mathrm{H}$, Syafruddin in the last decade, resistance to pathogens that cause Urinary Tract Infections (UTI) to one or more antibiotics is increasing, such as ampicillin and amoxicillin against Escherichia coli bacteria. Likewise, amikacin (32.5\%), nitrofurantoin $(26.7 \%)$ and imipenem $(3.7 \%)$ were resistant to Enterobacteriaceae in vitro. In addition, penicillin, cefuroxime, and sulfamethoxazole antibiotics have also been resistant to bacteria that cause UTI [4].

Researchers state that the discovery of new antibiotics against resistant Enterobacteriaceae is a high priority [8]. Natural product studies show significant progress in the discovery of new compounds that have antimicrobial activity. Plants are a source of natural compounds with antimicrobial activity, and there are still many new plants that may contain antimicrobial guiding compounds and new drugs. In addition, according to WHO, medicinal plants will be the best source to obtain various drugs [9]. Many plant extracts have been tested and can inhibit the growth of Escherichia coli. Research on plant extracts is still growing with the discovery of new compounds that can kill pathogenic microorganisms. Approximately $20 \%$ of the world's plants have been studied for their biological and pharmacological effects. Several new antibiotics that have been known on the market are known to be obtained from natural or semisynthetic sources [10]. One of these things is Aloe vera, or what we usually know as aloe vera.

Aloe vera, in Indonesia, has long been planted by the community as a family medicinal plant and an ornamental plant because of its unique shape. Along with the rapid development of science and technology, the use of aloe vera has been extensive in various fields, including cosmetics, raw materials for the pharmaceutical industry, to the food sector [11]. Aloe vera types are commonly cultivated, namely Aloe urocortin from Zanzibar, Aloe barbadensis Miller and Aloe Vulgaris. The species currently cultivated commercially in Indonesia is Aloe barbadensis Miler, a synonym for Aloe vera Linn [12].

Research on the effectiveness of aloe vera as an antibacterial has been carried out. The study stated that showing that aloe vera extract was able to inhibit the growth of aloe vera leaf extract could inhibit several Gramnegative bacteria, one of which was E. coli with the Minimum Inhibit Concentration (MIC) method [13]. The effectiveness of aloe vera as an antibacterial is proven because it has active substances such as saponins, tannins, flavonoids, anthraquinones and salicylic acid as antiseptics $[14 ; 15]$. Anthraquinones and saponins found in all Aloe vera leaves are responsible for direct antibacterial activity, and polysaccharides have indirect antibacterial activity, stimulating leukocyte phagocytosis to destroy bacteria [16]. Aloe vera is an antimicrobial substance and can also provide an analgesic effect. Besides 
that, several compounds act as antiinflammatory and antibacterial in Aloe vera leaves, such as campesterol, sitosterol, and lupeol $[9 ; 13]$.

Based on the description above, the authors are interested in examining the effectiveness of antibacterial against Escherichia coli by determining the inhibition of the growth of Escherichia coli bacteria in vitro. The research problem answered in this study was "Can aloe vera extract inhibit the growth of Escherichia coli bacteria In Vitro?" to know the effectiveness of aloe vera extract in inhibiting the growth of Escherichia coli bacteria.

\section{LITERATURE REVIEW}

Aloe vera (Aloe vera) is one of the most efficacious medicinal plants in curing various diseases. This plant has been used by the Samaritans around $1875 \mathrm{BC}$ and the ancient Egyptians around 1500 BC. Thanks to its properties, the ancient Egyptians called it the plant of immortality [18]. Phillip Miller discovered aloe vera in 1768, which was developed in the Caribbean islands and Barbados in the Atlantic Ocean in the 16th century known as Aloe vera, meaning the original Aloe. Then it expanded to America, Mexico, Venezuela, the Dominican Republic, and Australia. This plant is native to Africa, to be precise Ethiopia which belongs to the Liliaceae group. Aloe vera has various names, depending on the country or region where it is grown. Latin French, Portuguese and German: Aloe; English: Crocodiles tongues; Malaysia: Jadam; China: Luhui; Spain: Sa'villa; India: Musabbar; Tibetan: Jelly leek; Indians: Ailwa; Arabic: sabbar; Indonesia: Aloe vera; and the Philippines: Nassau [20].

Aloe vera is usually used as a hair fertilizer, wound healer, and skincare. This plant is useful as a raw material for the pharmaceutical and cosmetic industries. In addition, it is also used as an ingredient for making healthy foods and drinks. According to the records of an Arab geographer named Idris, aloe vera is a product of the Greek island of Socotra and has been known since the 4th century BC. Aloe vera has spread and cultivated widely throughout the world in temperate and tropical regions. Aloe vera first entered Indonesia brought by farmers of Chinese descent around the 17th century, which was used as an ornamental plant planted in the house's yard as a cure for burns or baldness. In the 1990s, West Kalimantan farmers began commercially cultivating aloe vera, processed into Aloe vera drinks [21].

There are more than 350 types of Aloe that belong to the Liliaceae tribe. Besides, not a few aloe vera, which is the result of crosses. According to Dowling, only three types of Aloe are cultivated commercially in the world, namely Curacao aloe or Aloe vera (Aloe barbadensis Miller), Cape aloe or Aloe ferox Miller, and Socotrine aloe, one of which is Aloe perryi Baker [21]. Of the three widely used types, the species Curacao aloe or Aloe vera (Aloe barbadensis Miller) was discovered by Phillip Miller, a botanist from England, in 1768. Aloe barbadensis Miller has binomial synonyms, namely Aloe vera and Aloe Vulgaris. Carl Linnaeus first described aloe vera in 1753 as Aloe perfoliata vera. Nicolas Laurens further described it in 1768 as Aloe vera [22].

Aloe vera is a low shrub, classified as a succulent plant. Its fleshy leaves are thick and contain a lot of mucus or gel. Aloe vera can be used as an ornamental plant, medicinal plant and drink. So it has the potential to be developed to meet the needs of the pharmaceutical, food and cosmetic industries [20]. Aloe vera (Aloe vera) can grow in dry areas, such as Africa, Asia, and America. Aloe vera can close the leaf stomata tightly in the dry season to avoid water loss from the leaves. Aloe vera can also grow in cold climates. Aloe vera is an efficient plant in water use because, from a physiological point of view, this plant belongs to the CAM (Crassulacean Acid Metabolism) type, a group of succulent plants with thick mesophyll or leaf flesh with drought-resistant properties. These 
CAM plants take $\mathrm{CO} 2$ at night and use it for photosynthesis during the day. In dark conditions, especially at night, the stomata or leaf mouths open so that that moisture can enter. Because at night, the air is cold, the water vapour is in the form of dew. Stomata that open at night have the advantage that they will not evaporate water from the plant body so that the water in the leaf body can be maintained. Therefore, aloe vera can survive in any dry conditions [21].

The weakness of aloe vera is that if it is planted in wet areas with high rainfall and is easily attacked by fungi, especially Fusarium sp. which attacks the base of the trunk [20]. The parts of the Aloe vera plant are stems, leaves [20;22], flowers, and roots. Aloe vera has leaves that consist of two parts, namely the outer skin of the leaf, which contains exudate or leaf sap (yellow sap) and the gel that is found on the inside of the leaf. Exudate is the sap that comes out of the leaves when cutting. This exudate is liquid, yellow in colour, and tastes bitter. At the same time, the gel is a slimy, colourless, and tasteless part. Aloe vera has many ingredients that are beneficial for health. The content of aloe vera (Aloe vera) is saponins, tannins, flavonoids, anthraquinone phenols and sterols [23; 24].

The parts of Aloe vera that are commonly used are the leaves, exudate or leaf sap and gel. Aloe vera leaves can be used directly, both traditional and in the form of extracts, to maintain the integrity of the antioxidant status in the body. Exudate or leaf sap, a bitter and thick liquid that flows out when Aloe vera leaves are cut, can be used traditionally, usually used directly for hair maintenance. The gel is the slimy part obtained by cutting the inside of the leaf after exudate is removed. It is cooling and easily damaged by oxidation, so further processing is needed to obtain a stable and durable gel. Several substances are contained in aloe vera gel, namely carbohydrates (glucomannan and acemannan), inorganic compounds, proteins, saccharides, vitamins, and saponins [25].
Based on research, aloe vera gel can help stimulate the immune system and stimulate fibroblasts, namely skin cells responsible for wound healing and contain elements of medicinal value, namely as antiinflammatory, antibacterial, antifungal and stimulate cell growth activity [26].

Escherichia coli forms circular, smooth colonies with visible angles. These bacteria typically give positive results on indole, lysine decarboxylase, mannitol and lactose fermentation and produce gas from glycine decarboxylase, mannitol and lactose fermentation and produce gas from glucose. Some strains of Escherichia coli produce hemolysis on blood agar. The urine test can be identified quickly by the appearance of hemolysis on blood agar, characteristic morphology with a "metallic lustre" colour on EMB agar, and a positive indole spot test. Escherichia coli is a bacterium commonly found in the intestines of humans as normal flora and warm-blooded animals. For the most part, Escherichia coli strains are not pathogenic. However, some strains such as Shiga toxin-producing E. coli (STEC) can cause infectious diseases with severe symptoms such as hemorrhagic colitis and Hemolytic Uremic Syndrome (SHU). The bacteria transmit the toxin to humans through ingestion of contaminated food such as raw or undercooked meat products, raw milk, contaminated raw vegetables. STEC can be turned off by thoroughly cooking food until all parts reach a temperature of $70^{\circ} \mathrm{C}$ or higher [1].

E. coli can cause disease because of its ability to multiply and spread widely in body tissues and the presence of several substances produced by these bacteria, including non-toxic and toxic substances. E. coli is a common bacterium causing urinary tract infections, especially in young women, by $90 \%$. Symptoms and signs experienced include frequent urination, dysuria, hematuria, pyuria. Back pain is usually associated with an upper urinary tract infection. None of these signs or symptoms is specific to E. coli infection. Urinary tract 
infections can cause bacteremia and clinical signs of sepsis [1].

Most UTIs affecting the bladder or kidneys in previously healthy hosts are caused by small amounts of the $\mathrm{O}$ antigen that bind to and produce specific virulence factors that facilitate colonization and subsequently cause infection. In this case, E. coli produces hemolysin, cytotoxic and invasive to host tissues [1].

E. coli is a common cause of diarrheal disease worldwide. Based on the virulence factors and the resulting disease, E. coli is classified into five types. Namely, this bacterium is a significant cause of diarrheal disease, especially in developing countries. EPEC bacteria attach to the mucosa of the small intestine. Its ability to cause disease depends on two things: the villous assemblage formed by the plasmid EPEC attachment factor (EAF) and the enterocyte-binding chromosomal locus that triggers tight attachment. After attachment, the number of microvilli decreases, the formation of actin filament pedestals or cuplike structures and the entry of EPEC into the mucosal cells. EPEC bacterial infection is characterized by clinical symptoms in watery stools, nausea, vomiting and fever. E. coli O25b/ST31 has become multiresistant to various antibiotics. This bacterium causes widespread disease because it has a plasmid-mediated resistance factor that encodes resistance to betalactam, fluoroquinolone and aminoglycoside antibiotics [1]. Extraction can be carried out from both fresh and dried ingredients.

Fresh simplicia: The process of preparing fresh simplicia to be extracted includes the following steps: wet sorting, washing, draining and if necessary, chopping or grating [27]. Wet sorting is done to separate dirt or other foreign materials. For example, simplicia made from the roots of a medicinal plant must be free from foreign materials such as soil, gravel, grass, stems, damaged root leaves and other plant organs.

Washing is done to remove soil and other impurities attached to the simplicia material. Washing is done with clean water, such as water from springs, wells, or tap water. The washing of simplicia materials that contain active substances that are readily soluble in water should be carried out in the shortest possible time. Washing cannot clean simplicia from all microbes because the washing water used usually contains several microbes. The method of sorting and washing dramatically affects the type and number of initial microbes of simplicia. For example, if the water used in microbial washing is dirty, the number of microbes on the surface of the simplicia material can increase, and the water on the surface of the material can accelerate microbial growth. The bacteria commonly found in water are Pseudomonas, Micrococcus, Bacillus, Streptococcus, Proteus, Enterobacter, and Escherichia groups [28].

Draining is done to reduce the amount of rinse water that is still attached to the simplicia and so that the impurities that are still present in the washing rinse water are also removed. Chopping is needed to expand the surface of the material to facilitate the extraction process. Some types of simplicia require chopping to facilitate the process of drying, packing and grinding. Chopping can be done "manually" or with an appropriate thickness chopper (up to a thickness of $3 \mathrm{~mm}$ or more). If it is too thick, the drying process will take too long and may rot or mould. Chopping that is too thin will result in damage to the chemical content due to oxidation or reduction. The chopper or knife used should be made of stainless steel.

The thinner the material to be dried, the faster the evaporation of water, thereby speeding up the drying time. However, slices that are too thin can also cause a reduction or loss of volatile nutrients, thus affecting the desired composition, smell and taste. Therefore, simplicia ingredients such as "temulawak", "temu giring", ginger, "kencur", and other similar ingredients, chopping that is too thin, is avoided to avoid reducing the essential oil content, unless the 
essential oil is not expected to be left in the simplicia. If fresh Simplicia is extracted without drying first, it can be grated. It is to simplify and maximize the filtering process.

Dry simplicia: The preparation of dry simplicia can be done from fresh ingredients that have gone through the above process or from dry ingredients obtained from suppliers.42 A suitable drying process can be done by: a) Oven with a temperature of not more than $60 \mathrm{oC}$, and b) Drying under indirect sunlight, such as using a solar tent with regulated airflow and in an area free from contamination.

Dry sorting is carried out to separate impurities, foreign organic matter, and simplicia damaged by the previous process. Dry sorting is also done to select good quality dried simplicia. Dry cleaning of Simplicia - If simplicia is obtained from the supplier in a dry state and is still dirty, wash and dry it again. Pollination - The initial process of making the extract is making dry Simplicia powder (pollination). Simplicia powder is made from simplicia with specific equipment to a certain degree of fineness. Extraction can be done by maceration, percolation, digestion, or reflux methods. The nature of the active substance in the material affects the extraction method and the type of solvent selected. In addition, the maceration and percolation methods can be modified using an extractor equipped with a heating mantle [42].

Maceration - Maceration is used for fresh, dry or powdered Simplicia whose active ingredients are not resistant to the heating process [29]. The solvent used is water or organic solvent. The advantage of maceration is that the operation and equipment are simple and easy. While the drawbacks include the time required to extract the material is quite long, the extraction is not perfect, the solvent used is significant.

The method is as follows: put 1 (one) part of simplicia into the macerator, add 10 (ten) parts of the filter and soak for 6 hours while stirring occasionally, then let stand for 24 hours. Separate the macerates with the separator, repeat two times with the same amount and type of solvent, and then collect all the macerates. If the maceration is dissolved in water, then add at least $10 \%$ ethanol. In addition to being a preservative, it also facilitates the evaporation of the macerate.

\section{RESEARCH METHOD}

This type of research design is Post Test Control Group Design by giving two control groups. The negative control used was sterile distilled water, and the positive control used was chloramphenicol antibiotic disc against the growth of $\mathrm{E}$. coli bacteria. As well as the inhibition test used using the agar diffusion test method (Kirby and Bauer method). The research was carried out from September 2019 to November 2019 at the UKI Medical Faculty Microbiology Laboratory, and the aloe vera extraction process was carried out at the UKI Medical Faculty Integrated Laboratory. Aloe vera (Aloe vera) was purchased at a traditional market in Cileungsi, West Java. The extraction process of aloe vera (Aloe vera) was carried out at the Research Laboratory of the Faculty of Medicine, Christian University of Indonesia. The bacterial sample used was Escherichia coli ATCC 25922 from the University of Indonesia. The samples used in this study were aloe vera extract in various concentrations of $20 \%, 40 \%, 60 \%, 80 \%, 100 \%$ and the antibiotic chloramphenicol as a positive control and sterile distilled water as a negative control. The formula used to use the sample size (duplication) is the Federer formula. The number of repetitions that can be done in each treatment group in this study is four times. In this study, aloe vera extract was diluted to obtain various concentrations in test tubes. After the desired concentration is formed, filter paper is put into it, which is placed on Milton Hilton Agar media to see the inhibition zone of the growth of Escherichia coli bacteria 
and repeated four times. Data was obtained descriptively by recording the inhibitory zone results of Gram-negative Escherichia coli bacteria after being treated with aloe vera extract at various concentrations, negative control (sterile distilled water), positive control (chloramphenicol). The data were analyzed using the Microsoft Excel 2013 application program and presented in tabulated form, which contains details of the inhibition zones formed by Aloe vera extract in various concentrations then analyzed and reviewed descriptively.

\section{RESULT AND DISCUSSION}

The aloe vera that has been cleaned and separated from the leaves is then dried and ground into a powder (dried Aloe vera simplicia). The simplicia is then weighed using a balance until it reaches a weight of 50 grams. Fifty grams of Aloe vera Simplicia was then dissolved with $200 \mathrm{ml}$ absolute ethanol, and the solution was then filtered using filter paper to produce a filtrate. To produce the extract, the solvent in the filtrate must be removed using a Vacuum Rotatory Evaporator. Thus, Aloe vera extract is obtained in liquid form with a very thick green consistency with a weight of 3.8 grams.

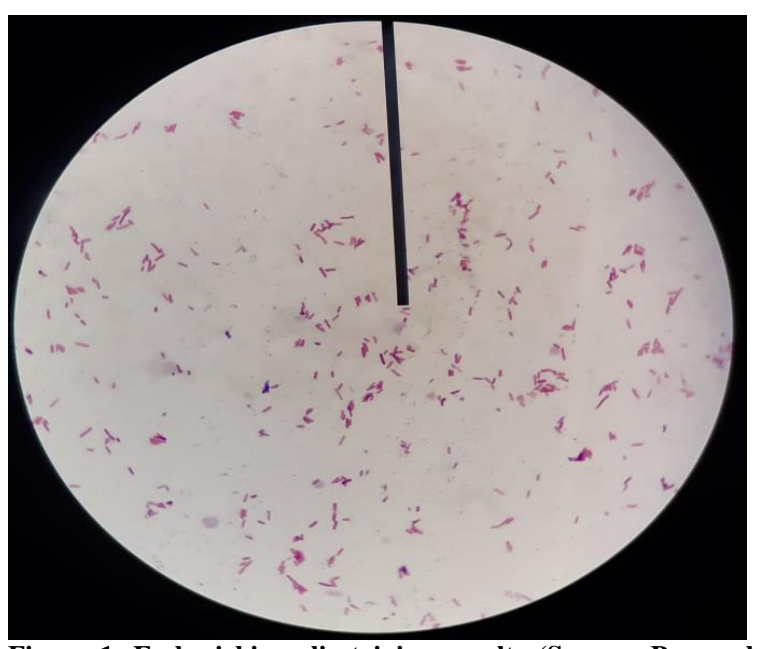

Figure 1. Escherichia coli staining results (Source: Personal document)

Gram staining is used to distinguish Gram-negative bacteria from Gram-positive bacteria and determine the morphology of the bacteria. Besides that, we can also know whether the bacterial culture results are pure or mixed with other colonies [30; 31]. Gram staining was carried out using a crystal solution of purple carbon, Lugol, alcohol and fuchsin, then viewed under a microscope with 1000x magnification. The results were rod-shaped and red bacteria, which means that the bacteria are Gramnegative following the nature of Escherichia coli.

Germination Agar EMB - Furthermore, isolates of E. coli bacteria were cultured on EMB media. The results were metallic green colonies. The surface of the colonies was convex with characteristic flat edges. It is following the opinion of S, Inggit et al. that EMB is a differential but selective medium to differentiate E. coli from other Gram-negative bacteria [32]. EMB Agar (Eosin Methylene Blue Agar) media is a selective medium and a differential medium. This medium is selective for growing gramnegative bacteria. This medium contains lactose which is helpful as a source of bacterial carbohydrates to distinguish between bacterial colonies that can ferment lactose and those that cannot ferment lactose. Meanwhile, eosin Y and methylene blue from EMB media are dyes that combine to form complexes at acidic $\mathrm{pH}$ and inhibit gram-positive bacteria [33].

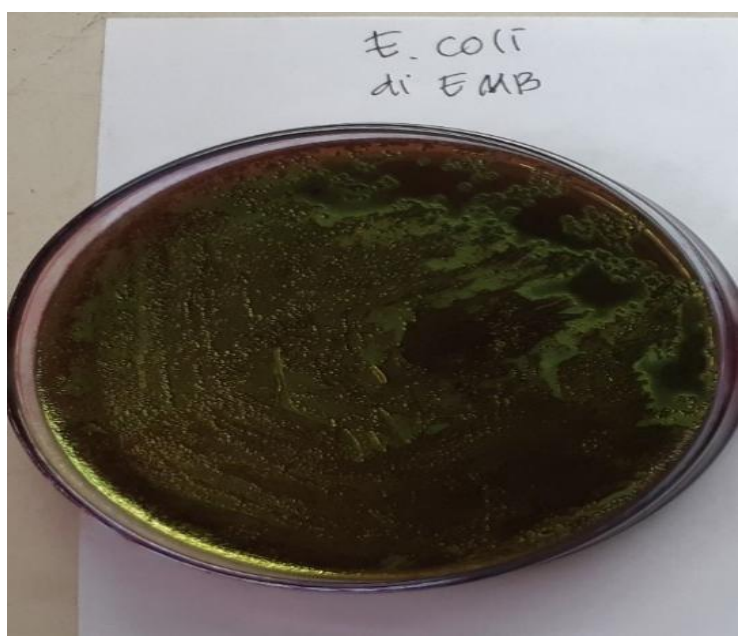

Figure 2. The results of planting Escherichia coli colonies on EMB media (Source: Personal document) 


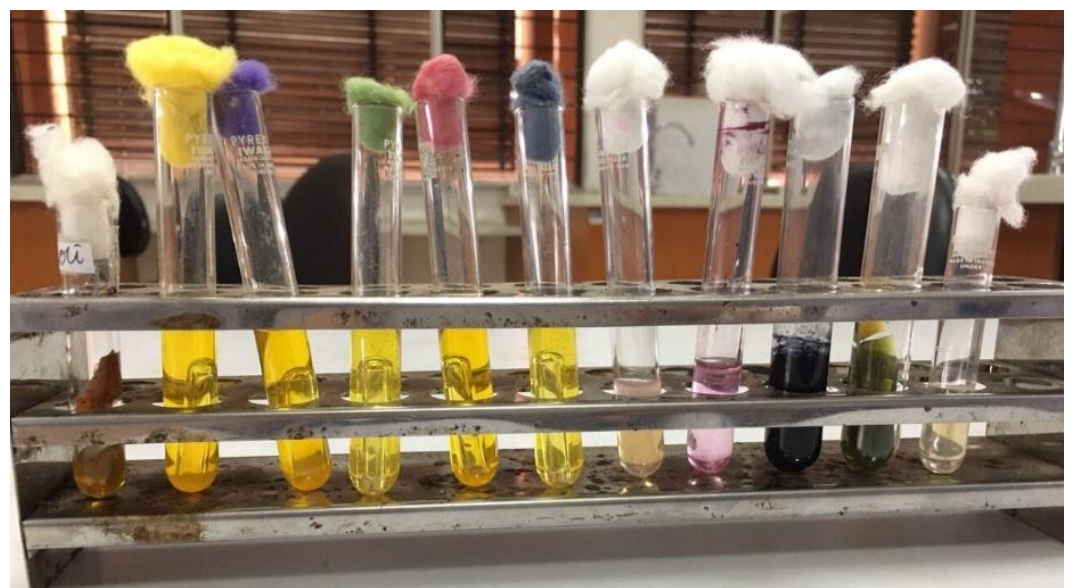

Figure 3. The results of the identification of Escherichia coli bacteria in the biochemical reactions of sugars, Sulfide Indole Motility, Cimon Agar Citrate and TSIA (Source: Personal document)

Biochemical Test - Based on the experimental results above, the results of the bacterial identification test were obtained with the following biochemical reactions: Confectionery - The results of the confectionery test obtained showed a positive result indicated by a change in colour to yellow. The test of sugars (sucrose, mannitol, glucose, lactose) aims to see the ability of microorganisms to ferment these sugars. According to Mahon, bacteria that can ferment carbohydrates show an acidic state. The acid formed will be broken down into $\mathrm{H} 2$ and $\mathrm{CO} 2$ so that gas will be formed, which can be seen from the Durham tube [30].

Sulfide Indole Motility - The indole test showed negative results because it indicated the dissolution of the amino benzaldehyde compound in water so that it did not form a red colour like a ring as indole formation [34]. Indole test is one of the components of amino acids found in proteins, so that microorganisms commonly use amino acids for protein decomposition. E. coli produces tryptophanase enzymes so that the decomposition of indole groups can be catalyzed from tryptophan [35].

Citrate Cimon Agar - Citrate Test aims to detect the ability of an organism to utilize citrate as the sole source of carbon and energy. The medium also contains inorganic ammonium salts, which are used as the sole nitrogen source. Utilization of citrate involves the citrate permease enzyme, which can break down citrate into oxaloacetate and acetate. Oxaloacetate is further broken down into pyruvate and $\mathrm{CO} 2$. Bacteria were inoculated in a medium containing sodium citrate and a $\mathrm{pH}$ indicator bromothymol blue. $\mathrm{Na} 2 \mathrm{CO} 3$ and $\mathrm{NH} 3$ from sodium citrate and ammonium salts resulted in an alkaline $\mathrm{pH}$, respectively. It causes the colour of the medium to change from green to blue. The observations for the Citrate test are negative, which is indicated by the absence of colour changes to the citrate test media.

Triple Sugar Iron Agar (TSIA) - TSIA or triple sugar iron agar is an enriched valuable medium in differentiating bacteria types based on their ability to break down glucose, lactose, sucrose and sulfide liberation [36]. Bacteria were inoculated by pricking the inside of the TSIA agar, scratching the agar's surface using a loop containing bacteria, and incubating at $37 \mathrm{oC}$ for 24 hours. In the TSIA test, the results were $+/+$ (fermenting glucose, lactose and sucrose) indicated by no change in the colour of the medium (still yellow). It is following the fermentation test results because bacteria can ferment all carbohydrates.

Inhibitory Test Results of Aloe Vera Extract on the Growth of Escherichia coli ATCC 25922 - Test of the inhibitory power of Aloe vera extract on the growth of Escherichia coli bacteria using Kirby 
Bauer's Disc Diffusion Method at concentrations of $20 \%, 40 \%, 60 \%, 80 \%$, $100 \%$ and with control positive in the form of chloramphenicol antibiotics and negative control using sterile distilled water. Escherichia coli was inoculated on MuellerHinton agar, then given test discs soaked with Aloe vera extract with various concentrations, positive control and negative control and then incubated at $37 \mathrm{oC}$ for 24 hours. The presence of an inhibition zone was indicated by the zone formation around the bacterial colony, then measured with a calliper. This treatment was repeated four times based on the Federer formula. Table 1 attached the results that aloe vera extract in concentrations of $20 \%, 40 \%, 60 \%$ and $80 \%$ did not have an antibacterial effect against Escherichia coli. It is evidenced by the absence of the diameter of the inhibition zone around the disc containing aloe vera extract. After four repetitions, no germ-free areas were found around the discs. Aquades as a negative control also did not produce inhibition against Escherichia coli. Only at a concentration of $100 \%$ can it provide an antibacterial effect against E. coli with an average inhibition zone count of $7.65 \mathrm{~mm}$. It can prove that the null hypothesis is rejected and the alternative hypothesis is accepted. Meanwhile, chloramphenicol as a positive control gave inhibition to the growth of Escherichia coli with an average inhibition zone of $21.48 \mathrm{~mm}$.

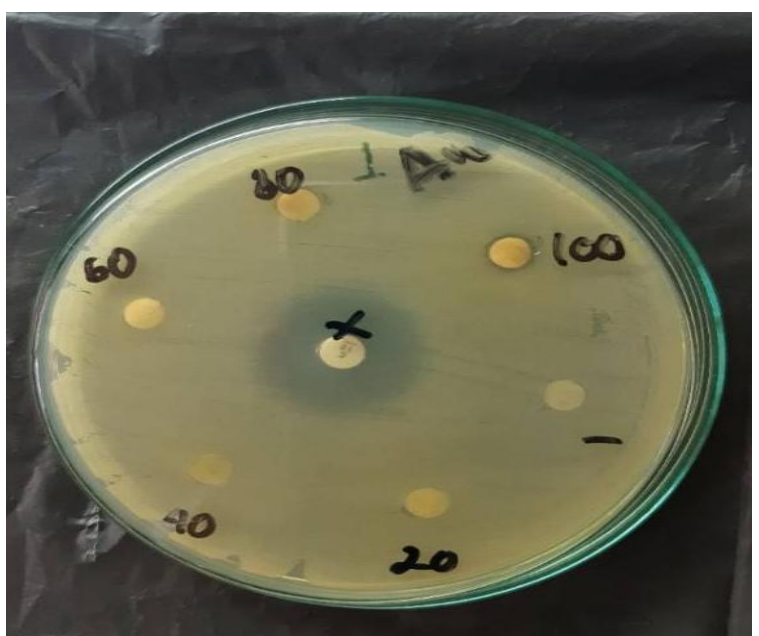

Figure 4. Inhibition zone of aloe vera extract against the growth of Escherichia coli bacteria on MHA media in the first experiment (Source: Personal document)

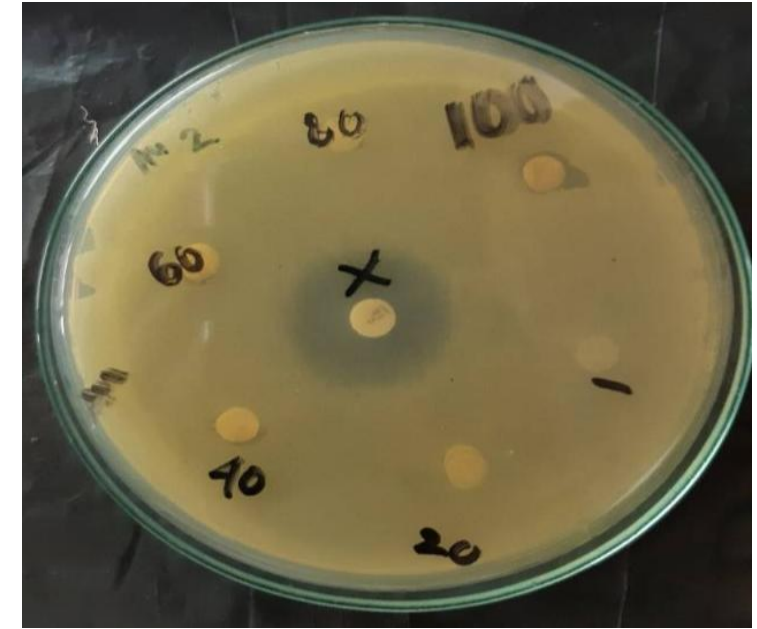

Figure 5. Inhibition zone of aloe vera extract against the growth of Escherichia coli bacteria on MHA media in the second experiment (Source: Personal document)

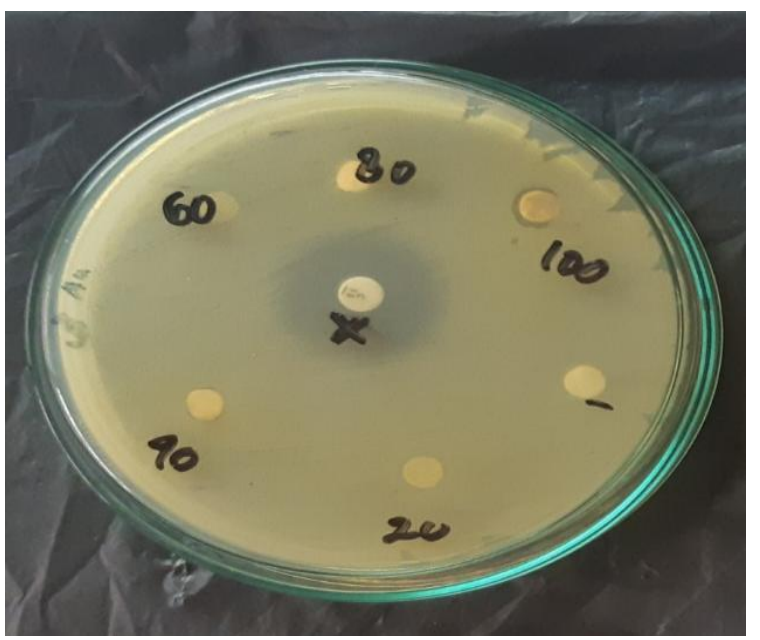

Figure 6. Inhibition zone of aloe vera extract against the growth of Escherichia coli bacteria on MHA media in the third experiment (Source: Personal document)

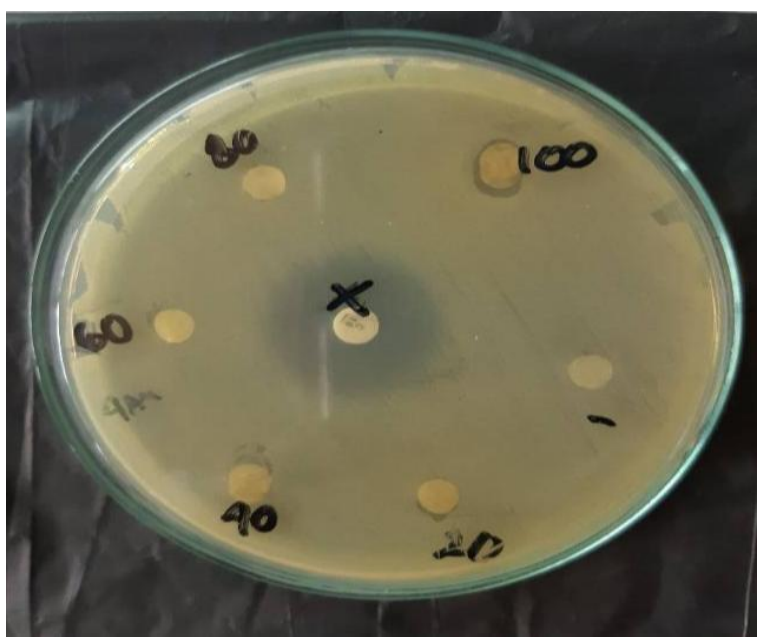

Figure 7. Inhibition zone of aloe vera extract against the growth of Escherichia coli bacteria on MHA media in the fourth experiment (Source: Personal document) 
Table 1. The results of the measurement of the inhibition zone of aloe vera (Aloe vera) extract on the growth of Escherichia coli bacteria

\begin{tabular}{|l|l|l|l|l|l|l|l|}
\hline \multirow{2}{*}{ Repetition of Treatment } & \multicolumn{7}{|l|}{ Inhibitory Zones in Various Concentrations (mm) } \\
\cline { 2 - 9 } & $\mathbf{2 0 \%}$ & $\mathbf{4 0 \%}$ & $\mathbf{6 0 \%}$ & $\mathbf{8 0 \%}$ & $\mathbf{1 0 0 \%}$ & Control (+) & Control (-) \\
\hline 1 & 0 & 0 & 0 & 0 & 6,67 & 21,9 & 0 \\
\hline 2 & 0 & 0 & 0 & 0 & 7,6 & 19,3 & 0 \\
\hline 3 & 0 & 0 & 0 & 0 & 7,35 & 21,75 & 0 \\
\hline 4 & 0 & 0 & 0 & 0 & 9,00 & 23,00 & 0 \\
\hline Average count & 0 & 0 & 0 & 0 & 7,65 & 21,48 & 0 \\
\hline
\end{tabular}

Aloe vera extract (Aloe vera) at a concentration of $100 \%$ proved to be quite effective in inhibiting the growth of Escherichia coli bacteria on Mueller-Hinton agar media. It is evidenced by forming a clear zone or halo around the disc of an average of $7.65 \mathrm{~mm}$. On the other hand, Aloe vera extract with concentrations of $20 \%, 40 \%, 60 \%$ and $80 \%$ did not produce a halo around the disc, then to improve accuracy, four replications were performed. In all of these replications, no zone of inhibition was found. It indicates that the effectiveness of the ethanolic extract of aloe vera gel at concentrations of $20 \%, 40 \%$, $60 \%$ and $80 \%$ used in this study on the growth of Escherichia coli could not be determined.

Differences in the effectiveness of aloe vera gel extract with previous literature can be caused by many factors, one of which is environmental factors where the plant grows. Different plant locations will produce different content of metabolites so that their activities will also be different [37]. In addition, the things that make aloe vera products decrease in effectiveness are, among others, influenced by the management and processing techniques. Freshly cut leaves must be produced immediately (no more than 4-6 hours) or refrigerated appropriately to prevent loss of biological activity, mainly through degradation decomposition of the gel matrix. When exposed to air, Aloe vera gel rapidly oxidizes, decomposes and loses a lot of its biological activity. The degradation process of the composition of aloe vera gel is caused by the natural reaction of enzymes and bacterial growth and oxygen, which causes the active compounds in the gel to be oxidized quickly. Optimal results from aloe vera gel will be seen if the Aloe vera leaves are processed immediately after harvest [38].

The effectiveness test of Aloe vera extract carried out using ethanol as a solvent was better than using a solvent in showing the inhibition zone on Escherichia coli growth, which was $6 \mathrm{~mm}$ using ethanol solvent and $3 \mathrm{~mm}$ using methanol solvent [39]. It shows that the method used will affect the antimicrobial effectiveness, extraction using ethanol as an organic solvent is considered to be better in liberating components with antimicrobial activity. Meanwhile, in the methanol extraction procedure, components that are important for the antibacterial activity of $\mathrm{E}$. coli are lost.

The maceration method of ethanol as a polar and non-polar solvent is useful for obtaining active substances in Aloe vera such as saponins, anthraquinones, tannins, flavonoids, phenols and sterols. These substances have various ways of inhibiting bacterial growth, such as: disrupting the function of bacterial cell membranes, breaking the glycoside bonds of bacteria on the cell wall, inactivating bacterial adhesion, inhibiting the process of cell wall formation and cell lysis, inhibiting bacterial growth by coagulating proteins and reducing integrity. cell membranes respectively $[11 ; 26 ; 27 ; 29$; 31].

Surya stated in her research that another possible cause is the interaction between the active antibacterial compounds contained in aloe vera that can affect the antibacterial action [11]. Other compounds will interfere with the penetration of the active compound into the bacterial cell wall to not effectively inhibit the bacteria. Differences in bacterial strains can also influence the above results due to differences in enzymes and other bacteria 
produced by bacteria. Different enzymes have different effects on the antibacterial substances contained in aloe vera [11]. Enzymes produced by bacteria can destroy or damage these antibacterial substances [1]. Bacteria synthesize enzymes that can convert active substances into inactive ones so that bacteria are resistant to antibacterial substances [11]. One of the ingredients contained in aloe vera is a glycoside group. Escherichia coli bacteria that have been resistant have aminoglycoside inactivating enzymes so that aminoglycosides fail to penetrate bacteria [11]. Another ingredient is saponins. Soetan et al. showed that saponins from aloe vera effectively inhibited Gram-positive bacteria but not Gram-negative [40]. Escherichia coli bacteria are Gram-negative bacteria with cell wall layers that are more complex than Gram-positive bacteria. The antibacterial compound of Aloe vera is more difficult to diffuse into the cell membrane of Gramnegative bacteria. Gram-negative bacteria have three layers, namely lipopolysaccharide, protein and phospholipid. The outermost membrane contains a hydrophilic porin. Meanwhile, aloe vera extract is hydrophobic. It makes it difficult for the extract components to enter bacterial cells [41].

The presence of an inhibition zone also depends on several factors such as the rate of diffusion, molecular size, stability of the antibacterial agent, the nature of the agar medium used, the number of organisms inoculated, the rate of bacterial growth, chemical concentration and incubation conditions. Positive control in chloramphenicol antibiotics, which was carried out, resulted in the largest inhibition zone compared to the inhibition zone produced by Aloe vera extract. Chloramphenicol provides a zone of inhibition by inhibiting protein or ribosomal synthesis. It is in line with Suryati's research which showed that the antibacterial effect of aloe vera extract at concentrations of $20 \%$, $40 \%, 60 \%, 80 \%$ and $100 \%$ was weaker than the antibiotic chloramphenicol [42].

\section{CONCLUSION}

Based on the results of the research conducted, it can be concluded that: a) Aloe vera extract made using absolute ethanol solvent has antibacterial activity against Escherichia coli at a concentration of $100 \%$, and b) Aloe vera extract made using ethanol solvent absolute concentrations of $20 \%$, $40 \%, 60 \%$ and $80 \%$ had no antibacterial activity. Therefore, it is recommended the following: a) to manage and process aloe vera properly in order to obtain sufficient active compounds to obtain the maximum inhibitory effect; b) extracting aloe vera using various methods to get the maximum inhibitory effect, and c) test the inhibitory power with different methods to get the maximum inhibitory effect.

\section{Acknowledgement: None}

\section{Conflict of Interest: None}

\section{Source of Funding: None}

\section{Ethical Approval: Approved}

\section{REFERENCES}

1. Brooks, G. F., Carroll, K. C., Butel, J. S., Morse, S. A., \& Mietzner, T. A. (2012). Jawetz, Melnick \& Adelberg Mikrobiologi Kedokteran Edisi 25, diterjemahkan dari Bahasa Inggris oleh Nugroho. AW, dkk, EGC, Jakarta, Indonesia.

2. Bai, X., Mernelius, S., Jernberg, C., Einemo, I. M., Monecke, S., Ehricht, R., ... \& Matussek, A. (2018). Shiga toxinproducing Escherichia coli infection in Jönköping county, Sweden: Occurrence and molecular characteristics in correlation with clinical symptoms and duration of stx shedding. Frontiers in cellular and infection microbiology, 8, 125.

3. Altmann, M., Wadl, M., Altmann, D., Benzler, J., Eckmanns, T., Krause, G., ... $\&$ an der Heiden, M. (2011). Timeliness of surveillance during outbreak of shiga toxin-producing Escherichia coli 
infection, Germany, 2011. Emerging infectious diseases, 17(10), 1906.

4. Exner, M., Bhattacharya, S., Christiansen, B., Gebel, J., Goroncy-Bermes, P., Hartemann, P., ... \& Trautmann, M. (2017). Antibiotic resistance: What is so special about multidrug-resistant Gramnegative bacteria?. GMS hygiene and infection control, 12.

5. Hadi, U., Kuntaman, K., Qiptiyah, M., \& Paraton, H. (2013). Problem of antibiotic use and antimicrobial resistance in Indonesia: are we really making progress?. Indonesian Journal of Tropical and Infectious Disease, 4(4), 5-8.

6. Fazeli, H., \& Salehi, R. (2008). Antibiotic resistance pattern in Shiga toxinproducing Escherichia coli isolated from diarrheal patients in Al-zahra Hospital, Isfahan, Iran. Research in Pharmaceutical Sciences, 2(1), 29-33.

7. Alvarez-Uria, G., Gandra, S., Mandal, S., \& Laxminarayan, R. (2018). Global forecast of antimicrobial resistance in invasive isolates of Escherichia coli and Klebsiella pneumoniae. International journal of infectious diseases, 68, 50-53.

8. Tacconelli, E., Carrara, E., Savoldi, A., Harbarth, S., Mendelson, M., Monnet, D. L., ... \& Zorzet, A. (2018). Discovery, research, and development of new antibiotics: the WHO priority list of antibiotic-resistant bacteria and tuberculosis. The Lancet Infectious Diseases, 18(3), 318-327.

9. Sahu, P. K., Giri, D. D., Singh, R., Pandey, P., Gupta, S., Shrivastava, A. K., ... \& Pandey, K. D. (2013). Therapeutic and medicinal uses of Aloe vera: a review. Pharmacology \& Pharmacy, 4(08), 599.

10. Handayani, C. V., Widjajanti, H., \& Nurnawati, E. (2020). Exploration of Endophytic Fungi Leaves of Plants (Paederia Foetida L.) Potentially As Producing Antibacterial Compounds (Doctoral dissertation, Sriwijaya University).

11. Yusmaini, H., \& Bahar, M. (2017). Antimicrobial effect of aloe vera (Aloe vera) extract against bacterial isolates that cause Acne Vulgaris in vitro. Jurnal Profesi Medika, 11(2), 63-72.

12. Coopoosamy, R. M., \& Magwa, M. L. (2007). Traditional use, antibacterial activity and antifungal activity of crude extract of Aloe excelsa. African Journal of Biotechnology, 6(20).

13. Masoumian, M., \& Zandi, M. (2017). Antimicrobial activity of some medicinal plant extracts against multidrug resistant bacteria. Zahedan Journal of Research in Medical Sciences, 19(11).

14. Tippayawat, P., Phromviyo, N., Boueroy, P., \& Chompoosor, A. (2016). Green synthesis of silver nanoparticles in aloe vera plant extract prepared by a hydrothermal method and their synergistic antibacterial activity. PeerJ, 4, e2589.

15. Rahardja, F., Puradisastra, S., \& Angelina, A. (2010). Aktivitas Antimikroba Gel Lidah Buaya (Aloe Vera L.) pada Acne Vulgaris yang Terinfeksi Staphylococcus sp. Secara In Vitro. Maranatha Journal of Medicine and Health, 10(1), 150782.

16. Nasri, H., Bahmani, M., Shahinfard, N., Nafchi, A. M., Saberianpour, S., \& Kopaei, M. R. (2015). Medicinal plants for the treatment of acne vulgaris: a review of recent evidences. Jundishapur journal of microbiology, 8(11).

17. Sahu, P. K., Giri, D. D., Singh, R., Pandey, P., Gupta, S., Shrivastava, A. K., ... \& Pandey, K. D. (2013). Therapeutic and medicinal uses of Aloe vera: a review. Pharmacology \& Pharmacy, 4(08), 599.

18. Nair, G. R., Naidu, G. S., Jain, S., Nagi, R., Makkad, R. S., \& Jha, A. (2016). Clinical effectiveness of aloe vera in the management of oral mucosal diseases-a systematic review. Journal of clinical and diagnostic research: JCDR, 10(8), ZE01.

19. Manvitha, K., \& Bidya, B. (2014). Aloe vera: a wonder plant its history, cultivation and medicinal uses. Journal of Pharmacognosy and Phytochemistry, 2(5), 85-88.

20. Gusviputri, A., PS, N. M., \& Indraswati, N. (2017). Making soap with aloe vera as a natural antiseptic. Widya Teknik, 12(1), 11-21. 
21. Purba, T., \& Kilmanun, J. C. (2016). Development Prospect of Aloe Vera Plant in Peatlands in West Kalimantan. Journal of Wetlands Environmental Management, 4(1).

22. Pegu, A. J., \& Sharma, M. A. (2019). Review on aloe vera. Int $\mathbf{J}$ Trend Sci Res Dev, 3(4), 35-40.

23. Benzidia, B., Barbouchi, M., Hammouch, H., Belahbib, N., Zouarhi, M., Erramli, H., ... \& Hajjaji, N. (2019). Chemical composition and antioxidant activity of tannins extract from green rind of Aloe vera (L.) Burm. F. Journal of King Saud University-Science, 31(4), 1175-1181.

24. Muthukumaran, P., Divya, R., Indhumathi, E., \& Keerthika, C. (2018). Total phenolic and flavonoid content of membrane processed Aloe vera extract: a comparative study. International Food Research Journal, 25(4).

25. Sharma, K., Mittal, A., \& Chauhan, N. (2015). Aloe vera as penetration enhancer. Inte J Drug Devel Res, 7(1), 3143.

26. Shedoeva, A., Leavesley, D., Upton, Z., \& Fan, C. (2019). Wound healing and the use of medicinal plants. Evidence-Based Complementary and Alternative Medicine, 2019.

27. Stephenson, T. (2016). The Curious Bartender's Gin Palace. Ryland Peters \& Small.

28. Chouhan, S. (2015). Enumeration and identification of standard plate count bacteria in raw water supplies. IOSR Journal of Environmental Science, Toxicology and Food Technology, 9(2), 67-73.

29. Madduluri, S., Rao, K. B., \& Sitaram, B. (2013). In vitro evaluation of antibacterial activity of five indigenous plants extract against five bacterial pathogens of human. International Journal of Pharmacy and Pharmaceutical Sciences, 5(4), 679684.

30. Mahon, C., Lehman, D., \& Manuselis, G. (2015). Texbook of diagnostic microbiologi 4th ed. USA: Saunders Elsevier.

31. Alhaj-Qasem, D. M., Al-Hatamleh, M. A., Irekeola, A. A., Khalid, M. F., Mohamud,
R., Ismail, A., \& Mustafa, F. H. (2020). Laborator.

32. Saridewi, I., Pambudi, A., \& Ningrum, Y. F. (2016). Analysis of Escherichia coli bacteria in ready-to-eat food in hospital canteen $\mathrm{X}$ and hospital canteen Y. Bioma, 12(2), 90-103.

33. Caires, C. S., Leal, C. R., Ramos, C. A., Bogo, D., Lima, A. R., Arruda, E. J., ... \& Nascimento, V. A. (2017). Photoinactivation effect of eosin methylene blue and chlorophyllin sodiumcopper against Staphylococcus aureus and Escherichia coli. Lasers in medical science, 32(5), 1081-1088.

34. Chaudhary, J., Mittal, V., Mishra, S., Daiya, A., Chowdhury, R., Laskar, I. R., \& Roy, R. K. (2020). A New Aggregation Induced Emission Active Halochromic White Light Emissive Molecule: Combined Experimental and Theoretical Study. The Journal of Physical Chemistry C, 124(28), 15406-15417.

35. Wood, W. A., Gunsalus, I. C., \& Umbreit, W. W. (1947). Function of pyridoxal phosphate: resolution and purification of the tryptophanase enzyme of Escherichia coli. Journal of Biological Chemistry, 170(1), 313-321.

36. Thompson, R., Perry, J. D., Stanforth, S. P., \& Dean, J. R. (2018). Rapid detection of hydrogen sulfide produced by pathogenic bacteria in focused growth media using SHS-MCC-GC-IMS. Microchemical Journal, 140, 232-240.

37. Dong, J., Ma, X., Wei, Q., Peng, S., \& Zhang, S. (2011). Effects of growing location on the contents of secondary metabolites in the leaves of four selected superior clones of Eucommia ulmoides. Industrial Crops and Products, 34(3), 1607-1614.

38. Vieira, J. M., Flores-López, M. L., de Rodríguez, D. J., Sousa, M. C., Vicente, A. A., \& Martins, J. T. (2016). Effect of chitosan-Aloe vera coating on postharvest quality of blueberry (Vaccinium corymbosum) fruit. Postharvest Biology and Technology, 116, 88-97.

39. Nabila, V. K., \& Putra, I. B. (2020). The effect of Aloe vera ethanol extract on the growth inhibition of Candida 
albicans. Med Glas (Zenica), 17(2), 485489.

40. Oyekunle, M. A., Aiyelaagbe, O. O., \& Fafunso, M. A. (2006). Evaluation of the antimicrobial activity of saponins extract of Sorghum bicolor L. Moench. African journal of Biotechnology, 5(23).

41. Perumal, S. (2015). Antibacterial Activity Of Euphorbia Hirta (L.): Euphorbiaceae And Isolation Of Its Bioactive Constituents (Doctoral dissertation).
42. Suryati, N., Bahar, E., \& Ilmiawati, I. (2018). Test of antibacterial effectiveness of aloe vera extract on the growth of Escherichia coli in vitro. jurnal kesehatan andalas, 6(3), 518-522.

How to cite this article: Parnomo T, Pohan DJ. Test the effectiveness of aloe vera extract on the growth of escherichia coli in vitro. Int $J$ Health Sci Res. 2021; 11(8): 211-224. DOI: https://doi.org/10.52403/ijhsr.20210831 